\title{
The efficacy of clove oil as an anaesthetic and in euthanasia procedure for small-sized tropical fishes
}

\author{
I. M. Fernandes ${ }^{a, b *}$, Y. F. Bastos ${ }^{b}$, D. S. Barreto ${ }^{b}$, L. S. Lourenço ${ }^{c}$ and J. M. Penha ${ }^{b, d}$ \\ a'Universidade Federal de Rondônia - UNIR, Campus Universitário de Rolim de Moura, Avenida Norte Sul, 7300, \\ Nova Morada, CEP 76940-000, Rolim de Moura, RO, Brazil \\ 'Programa de Pós-graduação em Ecologia e Conservação da Biodiversidade, Instituto de Biociências, Universidade \\ Federal de Mato Grosso - UFMT, Avenida Fernando Corrêa da Costa, 2367, CEP 78060-900, Cuiabá, MT, Brazil \\ 'Faculdade São Paulo - FSP, Avenida 25 de Agosto, 6961, São Cristovão, CEP 76940-000, Rolim de Moura, RO, Brazil \\ ${ }^{d}$ Laboratório de Ecologia e Manejo de Recursos Pesqueiros, Departamento de Botânica e Ecologia, \\ Instituto de Biociências, Universidade Federal de Mato Grosso - UFMT, Avenida Fernando Corrêa da Costa, 2367, \\ CEP 78060-900, Cuiabá, MT, Brazil \\ *e-mail: izaias.fernandes@unir.br
}

Received: September 21, 2015 - Accepted: April 7, 2016 - Distributed: August 31, 2017 (With 1 figure)

\begin{abstract}
Clove oil is used as a fish anesthetic because it is a natural and inexpensive product with low toxicity risks. The goal of the present study was to determine the appropriate concentration of clove oil for small-sized tropical fish to be used in mark-recapture studies or when individuals are to be sacrificed. We applied three different clove oil concentrations (D1=0.05 mL, D2 =0.10 mL and D3 $=0.20 \mathrm{~mL}$ per $500 \mathrm{~mL}$ of water) on three small-sized fish species. We found a negative relationship between induction time and treatment for two species (Hyphessobrycon sp.1 and Hemigrammus sp.), while concentration was unrelated to recovery time. Fish body length was positively related to induction time in the D2 treatment for Hemigrammus sp., and negatively for Hyphessobrycon sp.1 in the D1 treatment, but was unrelated to recovery time for three species and treatments. Mortality rates varied across treatments, but higher rates were observed with higher clove oil concentrations. We conclude that $0.05 \mathrm{~mL}$ of clove oil per $500 \mathrm{~mL}$ of water is the most efficient dose for studies where fish will be released back to their natural habitats, while $0.20 \mathrm{~mL}$ of clove oil is recommended for studies that require fish euthanization for further laboratory analyses.
\end{abstract}

Keywords: Eugenol, anesthesia, euthanasia, field experiment, fish manipulation.

\section{A eficiência do óleo de cravo como anestésico e em procedimentos de eutanaisa em peixes de pequeno porte}

\section{Resumo}

O óleo de cravo é recomendado como anestésico para peixes por ser produto de origem natural, baixo custo e apresentar poucos riscos de intoxicação. O objetivo deste trabalho foi determinar concentrações adequadas de óleo de cravo para anestesiar ou eutanasiar peixes de pequeno porte em ambiente natural. Foram testadas três concentrações do anestésico (D1=0,05 mL, D2=0,10 mL e D3=0,20 mL) em três espécies de peixes de pequeno. Houve uma relação negativa entre o tempo para a sedação dos indivíduos e a concentração para duas espécies (Hyphessobrycon sp.1 e Hemigrammus sp.), porém não foi encontrada relação entre o tempo para recuperação e as concentrações. Os exemplares maiores de Hemigrammus sp. levaram mais tempo para serem sedados no tratamento D2, já o contrário foi observado para Hyphessobrycon sp.1 no tratamento D1, enquanto que não houve efeito do comprimento no tempo de recuperação das três espécies. A mortalidade dos indivíduos variou entre as três concentrações do anestésico e as maiores taxas de mortalidade ocorreram nas maiores concentrações. Desse modo, a concentração de $0,05 \mathrm{~mL}$ é eficiente para estudos que envolvem manuseio e a soltura dos peixes, enquanto que a concentração de $0,20 \mathrm{~mL}$ é recomendada em estudos onde os peixes precisam ser sacrificados.

Palavras-chave: Eugenol, anestesia, eutanásia, experimento de campo, manipulação de peixes. 


\section{Introduction}

Capture, handling, and transport of fish can have a negative impact on their health and their growth. To resolve this problem, fish biologists have used a variety of anesthetics in attempts to reduce handling stress (Perdikaris et al., 2010). An emerging and efficacious anesthetic for use with fish is clove oil, which is extracted from flower buds, leaves and stems of clove trees (Syzygium aromaticum (L.) Merr. \& L.M. Perry and Myrcianthes fragrans (Sw.) McVaugh), (both Myrtaceae). The active ingredients are eugenol (4-allyl-2-methoxyphenol) and iso-eugenol (4-propenyl-2-methoxyphenol) (Keene et al., 1998; Prince and Powell, 2000). It has been used as fish anaesthetics in the aquaculture industry and has shown to have low intoxication and mortality risks (Soto and Burhanuddin, 1995; Griffiths, 2000; Inoue et al., 2011). Moreover, the use of this anesthetic is advantageous because it is relatively inexpensive, efficacious, cost effectiveness, safe and does not present risks for users or to the environment (Soto and Burhanuddin, 1995; Munday and Wilson, 1997; Guénette et al., 2007; Hisano et al., 2008; Lucena et al., 2013; Öğretmen et al., 2014).

Clove oil have been increasingly used as anaesthetic in mark-recapture studies in order to reduce handling stress in freshwater fish, allowing them to be collected, identified, measured, weighed and subsequently released back to their natural habitats (Munday and Wilson, 1997; Javahery et al., 2012). In addition, this anesthetic is used in artificial reproduction and chirurgic processes, as well as with live fish transportation (Javahery et al., 2012; Inoue et al., 2005) because it mitigates fish stress levels. It also reduces potential negative effects on fish homeostasis, so decreasing mortality rates (Inoue et al., 2005; Becker et al., 2012, 2013).

Like other anaesthetics, clove oil decreases fish neurosensory functions by acting upon the nervous system, mainly the cerebral cortex (Schreck and Moyle, 1990). It also has an inhibitory effect on the respiratory system of fish, resulting in a slowing of respiration rate (Keene et al., 1998). However, high concentrations of clove oil affect the brainstem, the respiratory system and the spinal cord, potentially causing respiratory failure and medullary collapse, which may lead to death (Schreck and Moyle, 1990). Therefore, better understanding the relationship between the anesthetic concentration and its effects on fish is critical for the success of studies where individuals are to be returned alive to their natural environment.

The concentration of the anesthetic will depend on whether the fish is to be anaesthetized or euthanized, according to the goals of the study (Silva et al., 2009). Smaller fishes respond to lower concentrations than larger fishes, thus the effect of clove oil will vary depending on the fish species and their sizes (Woody et al., 2002; Ross and Ross, 2008). Although clove oil is broadly utilized, information on its anesthetic effects on small fishes from tropical regions is currently lacking (Lucena et al., 2013). Therefore, determining the appropriate concentration of the anaesthetic will allow a reduction in unintentional fish mortality in studies that aim to return specimens alive to their natural habitat (e.g., mark-recapture studies or population monitoring). As a consequence, impacts on studied populations and communities will be minimized.

In the present study, we set out to determine empirically the appropriate concentration of clove oil to anaesthetize or euthanize three small-sized tropical fishes species. More precisely, we asked the following questions: (i) What is the ideal concentration for anesthesia and euthanasia of the tropical small fish? (ii) Is there variation in induction and recovery times across different clove oil concentrations and species? (iii) Do induction and recovery times depend on fish size and species? And (iv), do mortality rates differ across different clove oil concentrations and species?

\section{Material and Methods}

\subsection{Study area and sampling}

The experiment was conducted in the São Nicolau farm, localized at the left margin of the Juruena River, upper Tapajós River, Mato Grosso, Brazil. Data was collected in an artificial lake that was built on the farm to provide water for cattle $\left(9^{\circ} 49>28^{\prime} \mathrm{S}\right.$ and $58^{\circ} 15>27^{\prime}$ W). Fish were captured using a trawl $(6 \mathrm{~m} \times 2.8 \mathrm{~m} ; 2.5 \mathrm{~mm}$ mesh $)$ applied on the bottom of the lake and kept in containers filled with water from the same lake. For the experiment, we used 120 specimens from three abundant Characidae species: Hyphessobrycon sp.1 (40 individuals), Hyphessobrycon sp.2 (40 individuals) e Hemigrammus sp. (40 individuals) (See species details in Carvalho et al., 2013). The standard length varied between 8.19 and $34.92 \mathrm{~mm}$, with an average of $24.70 \mathrm{~mm}$ for Hyphessobrycon sp.1. In Hyphessobrycon sp. 2 the standard length ranged from 26.93 to $40.22 \mathrm{~mm}$ average of the $31.79 \mathrm{~mm}$, and for Hemigrammus sp. from 6.03 to $41 \mathrm{~mm}$, with an average of $27.49 \mathrm{~mm}$. Hyphessobrycon and Hemigrammus are two speciose genus of small-sized fishes from the Characidae family occurring from northern cis-Andean South America, including the Amazon, Orinoco, La Plata, and São Francisco river basins, and rivers of Guyana, Suriname, French Guyana, and northeastern Brazil. They have, respectively, 136 and 54 species recognized as valid (Britski and Lima, 2008; Lima et al., 2014; Ota et al., 2014). The experiment was carried out using the environmental conditions found in the lagoon in order to minimize the stress caused on individuals and, more importantly, to replicate the conditions experienced by fishes in mark-recapture studies.

\subsection{Protocol and experiment}

Due to its incomplete solubility in water, pure clove oil (90-95\% eugenol) was first dissolved in ethyl alcohol $(92.8 \%)$ in 1:9 ratio (clove oil: ethyl alcohol) following Anderson et al. (1997). This solution was then diluted in water in order to obtain concentrations of $0.05 \mathrm{~mL}(50 \mathrm{mg})$, $0.10 \mathrm{~mL}$ (100 mg), and $0.20 \mathrm{~mL}$ (200 mg) of clove oil per $500 \mathrm{~mL}$ of water. These concentrations were selected after reference to other studies (Anderson et al., 1997; Keene et al., 
1998; Griffiths, 2000). In order to control for the effects of stress and hypoxia, a control experiment was set up where the behavior and mortality rate of fishes were observed without the anaesthetic. Therefore, we had a total of four treatments $(\mathrm{D} 1=0.05 \mathrm{~mL}(50 \mathrm{mg}), \mathrm{D} 2=0.10 \mathrm{~mL}(100 \mathrm{mg})$, $\mathrm{D} 3=0.20 \mathrm{~mL}(200 \mathrm{mg})$ and control $)$ and 30 replicates for each of them (ten individuals of the each species per treatment, a total of 120 individuals).

The experiment consisted of placing one individual fish into a container filled with $500 \mathrm{~mL}$ of water with a specific concentration of clove oil solution. We then timed both induction time (i.e., the time required for the fish to become completely anaesthetized) and recovery time (i.e., the amount of time for the fish to recover after sedation). For more details about stage of anaesthesia in fish see Iversen et al. (2003). This procedure was repeated for each replicate across all treatments. Fish were considered anaesthetized when they exhibited balance loss as well as reduced opercular pumping and pectoral fin beating. In order to determine recovery time, the anaesthetized individual was then transferred into a container filled only with lake water and we recorded the time taken for it to recover balance and regular movements. Individuals that did not recover balance and regular movements in 3 minutes (in the D1 treatment $-0.05 \mathrm{~mL}$ ), 7 minutes (in the $\mathrm{D} 2$ treatment $-0.10 \mathrm{~mL}$ ) and 10 minutes (in the D3 treatment $-0.2 \mathrm{~mL}$ ) were immediately transferred for 30 minutes to another container in which water was constantly renewed. Individuals that did not exhibit any vital signs after this period were considered dead. These time period were chosen because the time required for the fish recovery is faster in low than high concentration of the clove oil (Anderson et al., 1997; Griffiths, 2000). When individuals were anaesthetized, we measured their standard length with calipers. After recovery, individuals were returned to the lake. Fish that died during the experiment were fixed in $10 \%$ formalin solution, preserved in $70 \%$ ethanol and stored in the Mato Grosso Federal University (UFMT) fish collection.

\subsection{Statistical analysis}

ANOVA permutation tests were used to assess whether standard length, induction and recovery time of the Hyphessobrycon sp.1, Hyphessobrycon sp.2 and Hemigrammus sp. varied across of the three treatments and to evaluate the effect of treatment on induction and recovery time of each species) and a multiple comparison Tukey post-hoc tests was used (Sokal and Rohlf, 1995). This test was chosen instead of ANOVA because the residuals of the ANOVA model were not normally distributed and it was not possible to normalize the data. Note that, since all individuals died on the $0.20 \mathrm{~mL}$ treatment, this treatment was excluded from the analysis of recovery time.

The relationships between standard length, induction time and recovery time were evaluated with linear regressions. As both induction and recovery times varied across treatments, regression models were built separately for each treatment and species. Residual normality was assessed with Lilliefors test (Kolmogorov-Smirnov) (Sokal and Rohlf, 1995). We were unable to use ANCOVA models in this analysis because regression lines exhibited non-parallelism, thus suggesting interactions between the different treatments and the standard length. Finally, differences among treatments in mortality rates were assessed using a Fisher's exact test (Sokal and Rohlf, 1995). All assumptions (i.e., homogeneity and linearity) for the parametric tests were met and analyses were performed in the R 2.15.2 statistical software (R Development Core Team, 2013).

\section{Results}

The standard length of individuals given treatment D1 (ANOVA: $\mathrm{F}_{2,27}=2.28 ; \mathrm{p}=0.12$ ) e D2 (ANOVA: $\mathrm{F}_{2,27}=2.21$; $\mathrm{p}=0.12$ ) showed no difference among species. However individuals of Hyphessobrycon sp.1 used in treatment D3 (ANOVA: $\mathrm{F}_{2,27}=15.92 ; \mathrm{p}<0.001$ ) and in the control $\left(\mathrm{F}_{2,27}=3.84 ; \mathrm{p}<0.034\right)$ were smaller than Hyphessobrycon sp.2 and Hemigrammus sp. ( $\mathrm{p}<0.001$, Tukey post-hoc tests). The induction time did not vary among species in either treatment D1 (ANOVA: $\mathrm{F}_{2,27}=0.64 ; \mathrm{p}=0.53$ ), D2 (ANOVA: $\mathrm{F}_{2,27}=0.68 ; \mathrm{p}=0.51$ ) or D3 (ANOVA: $\mathrm{F}_{2,27}=1.68 ; \mathrm{p}=0.20$ ). Recovery time of individuals showed no difference between the three fish species for the D1(ANOVA: $\mathrm{F}_{2,27}=0.27$; $\mathrm{p}=0.76$ ) and D2 treatments (ANOVA: $\mathrm{F}_{2,27}=2.57 ; \mathrm{p}=0.09$ ).

Induction time varied across the three treatments only for Hyphessobrycon sp.1 and Hemigrammus sp. (Table 1). As expected, individuals submitted to the highest dose (D3) were anaesthetized significantly faster than individuals submitted to the two lower concentrations of clove oil (D1 and D2) (Table 1). However, there was no significant difference between individual recovery times at the two lower clove oil concentrations (D1 and D2) (Table 1). The average time for individuals to fully recover balance and movement was 6.03 and 6.65 minutes for Hyphessobrycon sp.1, 5.3 and 4. 9 minutes for Hyphessobrycon sp.2 and 6.2 and 6.3 minutes for Hemigrammus sp. in treatment D1 and D2, respectively (Table 1 ). In the treatment with the highest clove oil concentration (D3) all individuals died thus recovery time could not be evaluated.

The analysis performed on fish standard length indicated that larger individuals became anaesthetized more quickly than smaller ones during the D1 treatment on Hyphessobrycon sp. $1\left(\mathrm{r}^{2}=0.35 ; \mathrm{df}=8 ; \mathrm{p}=0.04\right.$; Table 2$)$, while the converse occurred with treatment D2 on Hemigrammus sp. $\left(\mathrm{r}^{2}=0.60 ; \mathrm{df}=8 ; \mathrm{p}=0.005\right.$; Table 2$)$. No such affects were observed with the other treatments or species (Table 2). Additionally, smaller individual Hyphessobrycon sp.1 and Hemigrammus sp. exhibited a longer recovery time in treatment $\mathrm{D} 1\left(\mathrm{r}^{2}=0.78 ; \mathrm{df}=8\right.$; $\mathrm{p}<0.001$; Table 2 and $\mathrm{r}^{2}=0.37 ; \mathrm{df}=8 ; \mathrm{p}=0.03$; Table 2 ) but not on treatment D2 (Table 2).

Survival rates varied across treatments and species (Fisher's exact test; $\mathrm{p}<0.001$ ). In the control treatment we did not observe any mortality, while all fish died under treatment D3. In the other two treatments, the number of 
Table 1. Mean, standard deviation (sd) of the standard length, induction time (minutes), recovery time (minutes) and survived rate for Hyphessobrycon sp.1, Hyphessobrycon sp.2 and Hemigrammus sp. with each treatment and results of the Analysis of Variance (ANOVA).

\begin{tabular}{|c|c|c|c|c|c|c|c|}
\hline Species & Control & $\begin{array}{c}\text { D1 } \\
(0.05 \mathrm{~mL})\end{array}$ & $\begin{array}{c}\text { D2 } \\
(0.1 \mathrm{~mL})\end{array}$ & $\begin{array}{c}\text { D3 } \\
(0.2 \mathrm{~mL})\end{array}$ & $\mathbf{F}$ & df & $\mathbf{p}$ \\
\hline Hyphessobrycon sp.1 & \multicolumn{7}{|c|}{ Mean \pm sd } \\
\hline Standard length (mm) & $28.6 \pm 3.2^{\mathrm{a}}$ & $28.2 \pm 3.06^{\mathrm{a}}$ & $29.4 \pm 2.5^{\mathrm{a}}$ & $18.3 \pm 7.6^{\mathrm{b}}$ & 12.87 & 3.36 & $<0.001$ \\
\hline Induction time & na & $0.19 \pm 0.08^{\mathrm{a}}$ & $0.37 \pm 0.25^{\mathrm{b}}$ & $0.13 \pm 0.03^{\mathrm{a}}$ & 6.23 & 2.27 & 0.005 \\
\hline Recovery time & na & $6.03 \pm 3.1$ & $6.65 \pm 1.9$ & --- & 0.28 & 1.18 & 0.603 \\
\hline Survived* & 10 & 7 & 6 & 0 & --- & --- & $<0.001$ \\
\hline Hyphessobrycon sp.2 & \multicolumn{7}{|c|}{ Mean \pm sd } \\
\hline Standard length $(\mathrm{mm})$ & $32.0 \pm 1.1$ & $31.7 \pm 2.0$ & $31.5 \pm 2.9$ & $32.0 \pm 3.8$ & 0.09 & 3.36 & 0.965 \\
\hline Induction time & na & $0.28 \pm 0.29$ & $0.52 \pm 0.58$ & $0.11 \pm 0.02$ & 2.95 & 2.27 & 0.069 \\
\hline Recovery time & na & $5.3 \pm 2.7$ & $4.9 \pm 2.3$ & na & 0.011 & 1.18 & 0.744 \\
\hline Survived* & 10 & 9 & 7 & 0 & na & na & $<0.001$ \\
\hline Hemigrammus sp. & \multicolumn{7}{|c|}{ Mean \pm sd } \\
\hline Standard length (mm) & $30.0 \pm 3.2$ & $29.6 \pm 5.13$ & $29.0 \pm 3.14$ & $23.8 \pm 9.6$ & 0.53 & 3.36 & 0.661 \\
\hline Induction time & na & $0.23 \pm 0.05^{\mathrm{ab}}$ & $0.32 \pm 0.02^{\mathrm{a}}$ & $0.10 \pm 0.02^{\mathrm{b}}$ & 5.77 & 2.27 & 0.008 \\
\hline Recovery time & na & $6.2 \pm 2.9$ & $6.3 \pm 1.0$ & na & 0.01 & 1.18 & 0.890 \\
\hline Survived* & 10 & 7 & 5 & 0 & na & na & $<0.001$ \\
\hline
\end{tabular}

Different letters above value indicate significant statistical differences (Tukey post-hoc tests). --- all fish died. na = not applicable. *Fisher's exact test was used.

Table 2. Results of the linear regression of standard length on induction and recovery times for Hyphessobrycon sp.1, Hyphessobrycon sp.2 and Hemigrammus sp. for each treatment.

\begin{tabular}{|c|c|c|c|c|c|c|}
\hline \multirow{2}{*}{$\begin{array}{r}\text { Species } \\
\text { Hyphessobrycon sp.1 }\end{array}$} & \multicolumn{2}{|c|}{ D1 (0.05 mL) } & \multicolumn{2}{|c|}{ D2 (0.1 mL) } & \multicolumn{2}{|c|}{ D3 (0.2 mL) } \\
\hline & $\mathrm{r}^{2}$ & $\mathrm{p}$ & $\mathrm{r}^{2}$ & $\mathrm{p}$ & $\mathrm{r}^{2}$ & $\mathrm{p}$ \\
\hline Standard length vs. induction time & 0.35 & 0.04 & 0.09 & 0.67 & 0.07 & 0.55 \\
\hline Standard length vs. recovery time & 0.78 & $<0.001$ & 0.13 & 0.16 & na & na \\
\hline Hyphessobrycon sp.2 & & & & & & \\
\hline Standard length vs. induction time & 0.07 & 0.54 & 0.03 & 0.29 & 0.12 & 0.86 \\
\hline Standard length vs. recovery time & 0.09 & 0.62 & 0.08 & 0.58 & na & na \\
\hline Hemigrammus sp. & & & & & & \\
\hline Standard length vs. induction time & 0.11 & 0.18 & 0.60 & 0.005 & 0.25 & 0.07 \\
\hline Standard length vs. recovery time & 0.37 & 0.03 & 0.12 & 0.91 & na & na \\
\hline
\end{tabular}

individuals that died after anesthesia changed between species. In Hyphessobrycon sp.1 30\% died in treatment D1, and $60 \%$ died in treatment D2 (Figure 1a), 10\% died in treatment D1 and 20\% of Hyphessobrycon sp. 2 died in treatment D2 (Figure 1b). For Hemigrammus sp., 30\% died in treatment D1, and 50\% died in treatment D2 (Figure 1c).

\section{Discussion}

Even though induction time and recovery time did not vary between species, induction time varied across the three treatment for two species (Hyphessobrycon sp.1 and Hemigrammus sp.), with larger individuals exhibiting a longer induction time under treatment D2 for Hemigrammus sp., and a shorter recovery time under treatment D1 for Hyphessobrycon sp.1 and Hemigrammus sp. On the other hand, larger individuals of Hyphessobrycon sp. 1 became anaesthetized faster than smaller ones with treatment D1. Treatment D3 was not efficient for fish anaesthesia because it caused mortality of fish across all replicates. In contrast, $70 \%$ of individuals of Hyphessobrycon sp. 1 and Hemigrammus sp., and 90\% of individuals from Hyphessobrycon sp.2 survived after being anaesthetized under treatment D1, while mortality reached $20 \%$ for Hyphessobrycon sp.2, 50\% for Hemigrammus sp. and 60\% for Hyphessobrycon sp.1 with treatment D2.

Although we did not observe a negative relationship between concentration and induction time for all treatments, a concentration-dependant pattern is well known (Soto and Burhanuddin, 1995; Keene et al., 1998; Hisano et al., 2008; Woody et al., 2002; Walsh and Pease, 2002), including for other types of anaesthetics (Silva et al., 2013), so that increasing anaesthetic dose results in a decreased induction time (Hoskonen and Pirhonen, 2004; Roubach et al., 2005; Öğretmen et al., 2014). It was, consequently, unexpected that the longest induction time for Hyphessobrycon sp.1 and Hemigrammus sp., were observed with treatment D2 . 

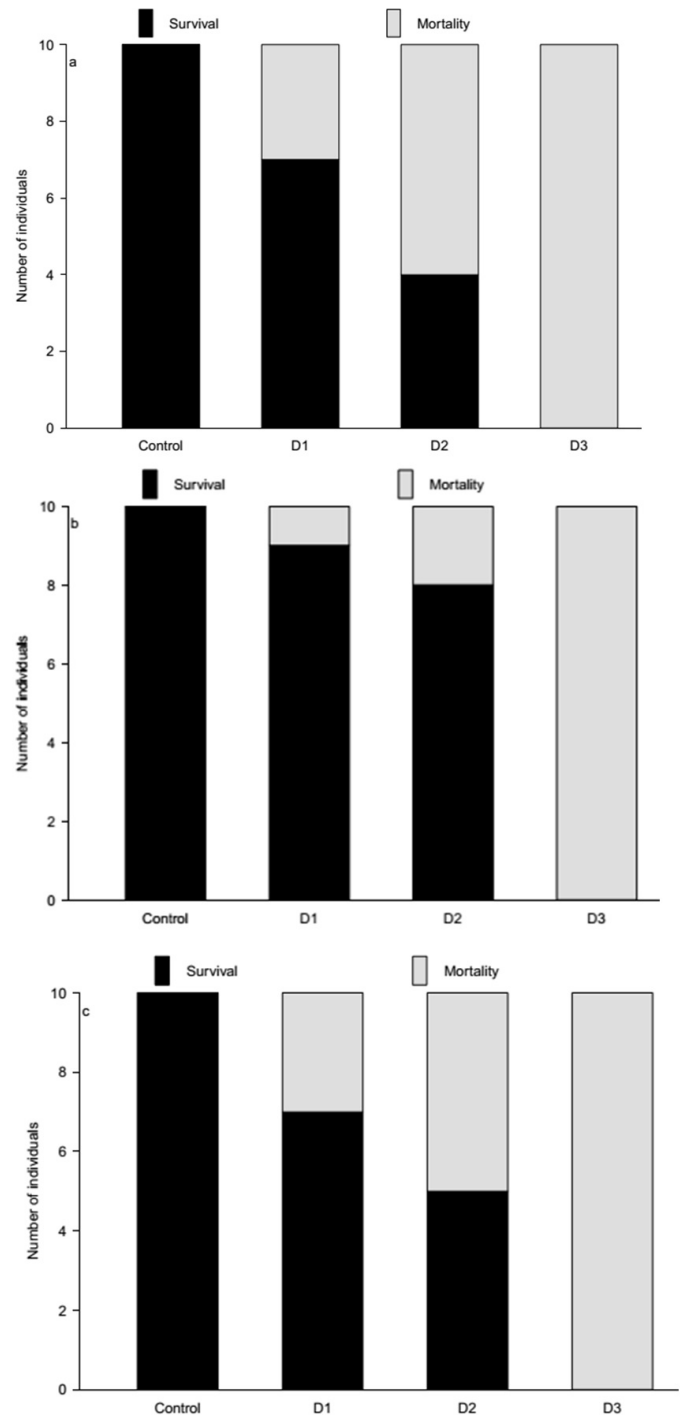

Figure 1. Number of individuals that survived and died in each treatment for Hyphressobrycon sp.1 (a), Hyphessobrycon sp.2 (b) and Hemigrammus sp. (c).

However, this probably occurred because we did not take into account the time of the day at which each experiment was performed. Treatment D2 was performed between 0800 and 1000 hours, which is a relatively cool period of the day. The other two treatments were performed in periods with higher temperatures: between 1000 and 1200 hours for treatment D1, and 1400 and 1600 hours for treatment D3. The higher temperatures occurring after 1000 hours increase fish metabolic rate and consequently, the effects of anaesthetic will be faster than lower temperatures (Hoskonen and Pirhonen, 2004). Opercular rates at high temperature are greater than those at low temperature. As the gills in fish are the main route of entry and the excretion of anaesthetics, increasing gill ventilation and cardiac rates at high temperature would increase the gill permeability of anaesthetic and result in increasing the efficacy of anaesthetic (Javahery et al., 2012). Thus, temperature is important environmental factor what could be considered when using clove oil as anaesthetic (Iversen et al., 2003; Javahery et al., 2012). Furthermore, individuals from Hyphessobrycon sp.1 specie used in treatment D3 are statically lower than treatment D1 and D2.

Studies analyzing the effect of standard length on induction and recovery times have reported conflicting results (Prince and Powell, 2000; Walsh and Pease, 2002; Woody et al., 2002; Hoskonen and Pirhonen, 2004; Perdikaris et al., 2010). As with our dissenting results for Hyphessobrycon sp.1 and Hemigrammus sp., larger bodied Whitefish (Coregonus lavaretus) had shorter induction times than smaller ones, while the opposite occurred in Rainbow Trout (Oncorhynchus mykiss) (Hoskonen and Pirhonen, 2004). The same study found that Brown Trout (Salmo trutta) and Atlantic Salmon (Salmo salar) of different body sizes did not differ in induction times (as we found for Hyphessobrycon sp.2). Of the few studies that have assessed the relationship between fish size and recovery time, two found no relationship (Hoskonen and Pirhonen, 2004; Prince and Powell, 2000), and one found that larger individuals had quicker recovery times than smaller ones (Woody et al., 2002). This parallels the current results for Hyphessobrycon sp.1 and Hemigrammus sp.

In general, clove oil was an efficient anaesthetic at low concentrations. However, the survival rates of fish decreased sharply at higher concentrations (Soto and Burhanuddin, 1995; Munday and Wilson, 1997; Iversen et al., 2003; Hisano et al., 2008; Inoue et al., 2011; Javahery et al., 2012), which was observed in part of the replicates of the D2 and all of the D3 treatments. Thus, the use of a $0.05 \mathrm{~mL}$ (or less) dose of clove oil (per $500 \mathrm{~mL}$ of water) as an anaesthetic should be recommended for mark-recapture and population monitoring studies (Ouedraogo et al., 2014). Clove oil concentrations above $0.05 \mathrm{~mL}$ per $500 \mathrm{~mL}$ of water increase considerably the mortality rates and are thus only recommended for studies in which fish species need to be sampled and sacrificed for later laboratory analyses (e.g., dietary or reproductive analysis). In such studies we suggest using the concentration of $0.20 \mathrm{~mL}$ (or $200 \mathrm{mg}$ ) clove oil per $500 \mathrm{~mL}$ of water in order to speed anaesthesia-induced death and so eliminate suffering when individuals are fixed in formalin solution.

In conclusion, the present study showed that the response of small bodied tropical fish to a clove oil anaesthetic are species-specific, but that all three species were anaesthetized in less than one minute and recovery the fully equilibrium and movement in less than 7 minutes, so showing close oil be an efficient anaesthetic for field studies of tropical fish. These results are similar to that found in others studies with large bodied and fisheries-exploited species in temperate (Anderson et al., 1997; Hoskonen and Pirhonen, 2004) and tropical regions (Simões et al., 2010; Bertozi Júnior et al., 2014; Sanchez et al., 2014a, b). Based on studies that have been assessed the clove oil efficiency, the appropriated anaesthetic dose is between $0.05 \mathrm{~mL}$ (50 $\left.\mathrm{mg} \mathrm{L}^{-1}\right)$ and $0.10 \mathrm{~mL}\left(100 \mathrm{mg} \mathrm{L}^{-1}\right)$ (Javahery et al., 
2012). However, in this study we had worked with three small bodied species which the largest individual sampled reached $41 \mathrm{~mm}$, thus we believe that concentration more than $0.05 \mathrm{~mL}\left(50 \mathrm{mg} / 500 \mathrm{~mL}\right.$ or $100 \mathrm{mg} \mathrm{L}^{-1}$ of water) should be not recommended for species the size of those in the current study.

\section{Acknowledgements}

We would like to thank the São Nicolau farm for the support, the National Council for Scientific and Technological Development (CNPq) for the Postdoctoral scholarship of I. M. Fernandes and L. S. Lourenço, the Coordination for the Improvement of Higher Education Personnel (CAPES) for the Postgraduate scholarship of D. S. Barreto and the Support Program for the Restructuring and Expansion of Federal Universities (REUNI) for the Postgraduate scholarship of Y. F. Bastos.

\section{References}

ANDERSON, W.G., MCKINLEY, R.S. and COLAVECCHIA, M., 1997. The use of clove oil as an anesthetic for rainbow trout and its effects on swimming performance. North American Journal of Fisheries Management, vol. 17, no. 2, pp. 301-307. http://dx.doi. org/10.1577/1548-8675(1997)017<0301:TUOCOA>2.3.CO;2.

BECKER, A.G., CUNHA, M.A., GARCIA, L.O., ZEPPENFELD, C.C., PARODI, T.V., MALDANER, G., MOREL, A.F. and BALDISSEROTTO, B., 2013. Efficacy of eugenol and the methanolic extract of Condalia buxifolia during the transport of the silver catfish Rhamdia quelen. Neotropical Ichthyology, vol. 11, no. 3, pp. 675-681. http://dx.doi.org/10.1590/S167962252013000300021 .

BECKER, A.G., PARODI, T.V., HELDWEIN, C.G., ZEPPENFELD, C.C., HEINZMANN, B.M. and BALDISSEROTTO, B., 2012. Transportation of silver catfish, Rhamdia quelen, in water with eugenol and the essential oil of Lippia alba. Fish Physiology and Biochemistry, vol. 38, no. 3, pp. 789-796. http://dx.doi. org/10.1007/s10695-011-9562-4. PMid:21972065.

BERTOZI JÚNIOR, M., DIEMER, O., NEU, D.H., BITTENCOURT, F., BOSCOLO, W.R. and FEIDEN, A., 2014. Benzocaína e eugenol como anestésicos para juvenis de Pimelodus britskii (mandi-pintado). Revista Brasileira de Ciências Agrárias, vol. 9, no. 1, pp. 134-138. http://dx.doi.org/10.5039/agraria.v9i1a2882.

BRITSKI, H.A. and LIMA, F.C., 2008. A new species of Hemigrammus from the upper rio Tapajós basin in Brazil (Teleostei: Characiformes: Characidae). Copeia, vol. 3, no. 3, pp. 565-569. http://dx.doi.org/10.1643/CI-07-134.

CARVALHO, L.N., LIMA-FILHO, J.A., RODRIGUES, R.R. and ZUANON, J., 2013. Peixes de Igarapés da Fazenda São Nicolau, Bacia do Rio Juruena. In: D.J. RODRIGUES, T.J. IZZO and L.D. BATTIRROLA, eds. Descobrindo a Amazônia Meridonal: biodiversidade da Fazanda São Nicolau. Cuiabá: Pau e Prosa Comunicação, pp. 105-122.

GRIFFITHS, S.P., 2000. The use of clove oil as an anaesthetic and method or sampling intertidal rockpool fishes. Journal of Fish Biology, vol. 57, no. 6, pp. 1453-1464. http://dx.doi. org/10.1111/j.1095-8649.2000.tb02224.x.
GUÉNETTE, S.A., UHLAND, F.C., HÉLIE, P., BEAUDRY, F. and VACHON, P., 2007. Pharmacokinetics of eugenol in rainbow trout (Oncorhynchus mykiss). Aquaculture, vol. 266, no. 1, pp. 262-265. http://dx.doi.org/10.1016/j.aquaculture.2007.02.046.

HISANO, H., ISHIKAWA, M.M., FERREIRA, R.Á., BULGARELLI, A.L., COSTA, T.R. and PÁDUA, S.B., 2008. Tempo de indução e de recuperação de dourados Salminus brasiliensis (Cuvier, 1816), submetidos a diferentes concentrações de óleo de cravo Eugenia sp. Acta Scientiarum Biological Science, vol. 30, no. 3, pp. 303-307.

HOSKONEN, P. and PIRHONEN, J., 2004. Temperature effects on anaesthesia with clove oil in six temperate-zone fishes. Journal of Fish Biology, vol. 64, no. 4, pp. 1136-1142. http://dx.doi. org/10.1111/j.1095-8649.2004.00359.x.

INOUE, L.A.K.A., AFONSO, L.O.B., IWAMA, G.K. and MORAES, G., 2005. Effects of clove oil on the stress response of matrinxã (Brycon cephalus) subjected to transport. Acta Amazonica, vol. 35, no. 2, pp. 289-295. http://dx.doi.org/10.1590/ S0044-59672005000200018.

INOUE, L.A.K.A., BOIJINK, C.L., RIBEIRO, P.T., SILVA, A.D. and AFFONSO, E.G., 2011. Avaliação de respostas metabólicas do tambaqui exposto ao eugenol em banhos anestésicos. Acta Amazonica, vol. 41, no. 2, pp. 327-332. http://dx.doi.org/10.1590/ S0044-59672011000200020.

IVERSEN, M., FINSTAD, B., MCKINLEY, R.S. and ELIASSEN, R.A., 2003. The efficacy of metomidate, clove oil, Aqui-S ${ }^{\mathrm{TM}}$ and Benzoak ${ }^{\circledR}$ as anaesthetics in Atlantic salmon (Salmo salar L.) smolts, and their potential stress-reducing capacity. Aquaculture, vol. 221, no. 1-4, pp. 549-566. http://dx.doi.org/10.1016/S00448486(03)00111-X.

JAVAHERY, S., NEKOUBIN, H. and MORADLU, A.H., 2012. Effect of anaesthesia with clove oil in fish. Fish Physiology and Biochemistry, vol. 38, no. 6, pp. 1545-1552. http://dx.doi. org/10.1007/s10695-012-9682-5. PMid:22752268.

KEENE, J.L., NOAKES, D.L., MOCCIA, R.D. and SOTO, C.G., 1998. The efficacy of clove oil as an anaesthetic for rainbow trout, Oncorhynchus mykiss (Walbaum). Aquaculture Research, vol. 9, no. 2, pp. 89-101. http://dx.doi.org/10.1111/j.1365-2109.1998. tb01113.x.

LIMA, F.C., COUTINHO, D.P. and WOSIACKI, W.B., 2014. A new Hyphessobrycon (Ostariophysi: Characiformes: Characidae) from the middle Amazon basin, Brazil. Zootaxa, vol. 3872, no. 2, pp. 167-179. http://dx.doi.org/10.11646/zootaxa.3872.2.3. PMid:25544078.

LUCENA, C.A., CALEGARI, B., PEREIRA, E. and DALLEGRAVE, E., 2013. O uso de óleo de cravo na eutanásia de peixes. Bolletin Sociedade Brasileirade Ictiologia, vol. 105, pp. 20-24.

MUNDAY, P.L. and WILSON, S.K., 1997. Comparative efficacy of clove oil and other chemicals in anaesthetization of Pomacentrus amboinensis, a coral reef fish. Journal of Fish Biology, vol. 51, no. 5, pp. 931-938.

ÖĞRETMEN, F., GÖLBAŞI, S., INANAN, B.E., KIZAK, V. and KAYIM, M., 2014. Use of clove oil and eugenol to anesthetize fingerling Shabut Barbus grypus. North American Journal of Aquaculture, vol. 76, no. 1, pp. 9-13. http://dx.doi.org/10.1080/ 15222055.2013.824942.

OTA, R.P., LIMA, F.C. and PAVANELLI, C.S., 2014. A new species of Hemigrammus Gill, 1858 (Characiformes: Characidae) from the rio Madeira and rio Paraguai basins, with a redescription of 
H. lunatus. Neotropical Ichthyology, vol. 12, no. 2, pp. 265-279. http://dx.doi.org/10.1590/1982-0224-20130176.

OUEDRAOGO, C., CANONNE, M., D'COTTA, H., BAROILLER, J.F. and BARAS, E., 2014. Minimal body size for tagging fish with electronic microchips as studied in the Nile Tilapia. North American Journal of Aquaculture, vol. 76, no. 3, pp. 275-280. http://dx.doi.org/10.1080/15222055.2014.911228.

PERDIKARIS, C., NATHANAILIDES, C., GOUVA, E., GABRIEL, U.U., BITCHAVA, K., ATHANASOPOULOU, F., PASCHOU, A. and PASCHOS, I., 2010. Size-relative effectiveness of clove oil as an anaesthetic for rainbow trout (Oncorhynchus mykiss Walbaum, 1792) and goldfish (Carassius auratus Linnaeus, 1758). Acta Veterinaria, vol. 79, no. 3, pp. 481-490. http://dx.doi. org/10.2754/avb201079030481.

PRINCE, A. and POWELL, C., 2000. Clove oil as an anesthetic for invasive field procedures on adult rainbow trout. North American Journal of Fisheries Management, vol. 20, no. 4, pp. 1029-1032. http://dx.doi.org/10.1577/1548-8675(2000)020<1029:COAA $\mathrm{AF}>2.0 . \mathrm{CO} ; 2$.

R DEVELOPMENT CORE TEAM, 2013 [viewed 10 January 2012]. $R$ : a language and environment for statistical computing. [online]. Vienna: R Foundation for Statistical Computing. Available from: http://www.r-project.org/

ROSS, L.G. and ROSS, B., 2008. Anaesthetic and sedative techniques for aquatic animals. 3rd ed. Oxford: Blackwell Publishing. 240 p. http://dx.doi.org/10.1002/9781444302264.

ROUBACH, R., GOMES, L.C., LEÃO FONSECA, F.A. and VAL, A.L., 2005. Eugenol as an efficacious anaesthetic for tambaqui, Colossoma macropomum (Cuvier). Aquaculture Research, vol. 36, no. 11, pp. 1056-1061. http://dx.doi.org/10.1111/j.13652109.2005.01319.x.

SANCHEZ, M.D.S., RODRIGUES, R.A., NUNES, A.L., OLIVEIRA, A.D.S., FANTINI, L.E. and DE CAMPOS, C.M., 2014a. Effect of menthol and eugenol on the physiological responses of pacu Piaractus mesopotamicus. Semina: Ciências Agrárias, vol. 35, no. 4, pp. 2799-2807.
SANCHEZ, M.D.S., RODRIGUES, R.A., NUNES, A.L., OLIVEIRA, A.D.S., FANTINI, L.E. and CAMPOS, C.M., 2014b. Physiological responses of cacharas Pseudoplatystoma reticulatum submitted to natural anesthetics. Semina: Ciências Agrárias, vol. 35, no. 2, pp. 1061-1069.

SCHRECK, C.B. and MOYLE, P.B., 1990. Methods for fish biology. Maryland: American Fisheries Society.

SILVA, E.M.P., OLIVEIRA, R.H.F., RIBEIRO, M.A.R. and COPPOLA, M.P., 2009. Efeito anestésico do óleo de cravo em alevinos de lambari. Revista de Ciência Rural, vol. 39, no. 6, pp. 1851-1856. http://dx.doi.org/10.1590/S0103-84782009005000127.

SILVA, L., SILVA, D., GARLET, Q., CUNHA, M., MALLMANN, C.A., BALDISSEROTTO, B., LONGHI, S., PEREIRA, A.M. and HEINZMANN, B.M., 2013. Anesthetic activity of Brazilian native plants in silver catfish (Rhamdia quelen). Neotropical Ichthyology, vol. 11, no. 2, pp. 443-451. http://dx.doi.org/10.1590/ S1679-62252013000200014.

SIMÕES, L.N., PAIVA, G. and GOMES, L., 2010. Óleo de cravo como anestésico para adultos de tilápia do Nilo. Pesquisa Agropecuária Brasileira, vol. 45, no. 12, pp. 1472-1477. http:// dx.doi.org/10.1590/S0100-204X2010001200019.

SOKAL, R.R. and ROHLF, J.F., 1995. Biometry: the principles and practice of statistics in biological research. New York: W.H. Freeman. 404 p.

SOTO, C.G. and BURHANUDDIN, G., 1995. Clove oil as a fish anaesthetic for measuring length and weight of rabbitfish (Siganus lineatus). Aquaculture, vol. 136, no. 1, pp. 149-152. http://dx.doi.org/10.1016/0044-8486(95)01051-3.

WALSH, C.T. and PEASE, B.C., 2002. The use of clove oil as an anaesthetic for the longfinned eel, Anguilla reinhardtii (Steindachner). Aquaculture Research, vol. 33, no. 8, pp. 1-9. http://dx.doi.org/10.1046/j.1365-2109.2002.00701.x.

WOODY, C.A., NELSON, J. and RAMSTAD, K., 2002. Clove oil as an anaesthetic for adult sockeye salmon: field trials. Journal of Fish Biology, vol. 60, no. 2, pp. 340-347. http://dx.doi. org/10.1111/j.1095-8649.2002.tb00284.x. 